\title{
Creativity, Production Engineering and entertainment industry
}

\author{
Vinícius Carvalho Cardoso* and Gabriel Bouhid Barradas
}

*Correspondence:

vinicius@poli.ufrj.br

Federal University of Rio de

Janeiro, Rio de Janeiro, Brazil

\begin{abstract}
In recent years, humanity has entered a new factory period, an age of electronic devices. The gadget-man working set and the mobility and abstract learning required by such gadgets leads Flusser (Mundo Codificado, 1st edn. Cosac Naify, São Paulo, 2007) to pose the question: what will factories be like in the future? We believe that this factory will be a place of creation and learning. As well as the mass production by machines allowed the widespread of various products and food, these electronic devices will free people for creative activities and mobility. Production Engineering must adapt and anticipate this new manufacturing paradigm, working on gradual adaptation of existing organizations and on the development of new organizations for this gadgets age. It is the production engineer role to study ways to better manage and organize factories and productive environments with a focus on creativity. In this paper, we present the theoretical foundations for Organizational Creativity_fundamental structure of the entertainment industries - under a standpoint of Production Engineering, highlighting the relationships that can open paths for the Production Engineering entry into these future factories. We hope to arouse interest of researchers and students alike for this field of knowledge that is each time harder to remain ignored in our society. We also hope to show entertainment industry members how the harmonization with Production Engineering tools may add to their job.
\end{abstract}

\section{Background}

Flusser (2007) argues that by studying the history of factories one can understand the history of humanity, involving the lives, thoughts, actions and sufferings of the people. His work divides history into four manufacturing periods: in the first period-Handman uses his own hands to act in the world, being in direct contact with nature but being defenseless. In the second period-Tools-the man uses tools for the transformation of the natural world into the cultural world. During this period the man surrounds himself by tools, alienating himself from the world, getting protected from nature, but at the same being imprisoned by the culture he creates, thus becoming part of the cultural world. There is high mobility in these manufacturing processes since the factory exists wherever the man is. He can even make his own tools wherever he is and carry out his manufacturing activities, the tool being a replaceable and changeable object. The third period-Machines-is the one in which the tables are turned. Now the machine becomes constant, absorbing raw materials and turning them into cultural products,

(c) 2016 The Author(s). This article is distributed under the terms of the Creative Commons Attribution 4.0 International License (http://creativecommons.org/licenses/by/4.0/), which permits unrestricted use, distribution, and reproduction in any medium, provided you give appropriate credit to the original author(s) and the source, provide a link to the Creative Commons license, and indicate if changes were made. 
while the man becomes the replaceable variable-if man "breaks", he is replaced. With this further step towards man's alienation, the factory adopts fixed positioning, housing machines, as is still common today. It is in this industrial context that Production Engineering blooms, studying the organization and solutions for problems occurring in Machine Era factories.

In recent years, however, humankind entered a new manufacturing period, the period of the Electronics. Unlike the machine, that is only capable of simulating the physiological functions of man, the electronics are focused on neurological functions, an attribute that brings major changes to production methods. First, in the current context, man once again becomes constant, but also the device occupies this position, they can only work together. Second, the trend in electronics is increasingly mobility, which returned a freedom to work of the man who had long ago been removed, the freedom of producing, at any given time, anywhere he is. Finally, these electronic devices require abstract learning, which can only be carried out from disciplines that still largely do not exist. So, after presenting this panorama, Flusser (2007) poses the question: what will factories be like in the future?

We believe the factory of the future will be a place of creation and learning. As the factory during the period of the machines allowed the popularization of various goods and food from mass production systems-which not only improved, as it allowed people's lives, being noteworthy the exponential population growth since the nineteenth century-electronic equipment free people to creative activities and mobility.

Production Engineering must adapt and anticipate this new industrial paradigm, working in the gradual adaptation of existing organizations and the development of new organizations to the period of the devices. It is the role of the production engineer to study ways to better manage and organize the factory and the productive environment with a focus on creativity - a word that, due to its immaterial nature, still faces resistance in the field of engineering when it comes to management and organization, although, ironically, it is exactly the way the engineer operates. The engineer is already, by nature, a designer, and the difference between our current period and the former ones is precisely the popularization of the ability to design.

In this paper, as illustrated in Fig. 1, we discuss the concepts of Organizational Creativity and its tight relationship with the future of Production Engineering. It is our belief, as presented in a brief discussion, that production engineers working and studying the entertainment industry may prove to be the first ones to enjoy this new trend. Some

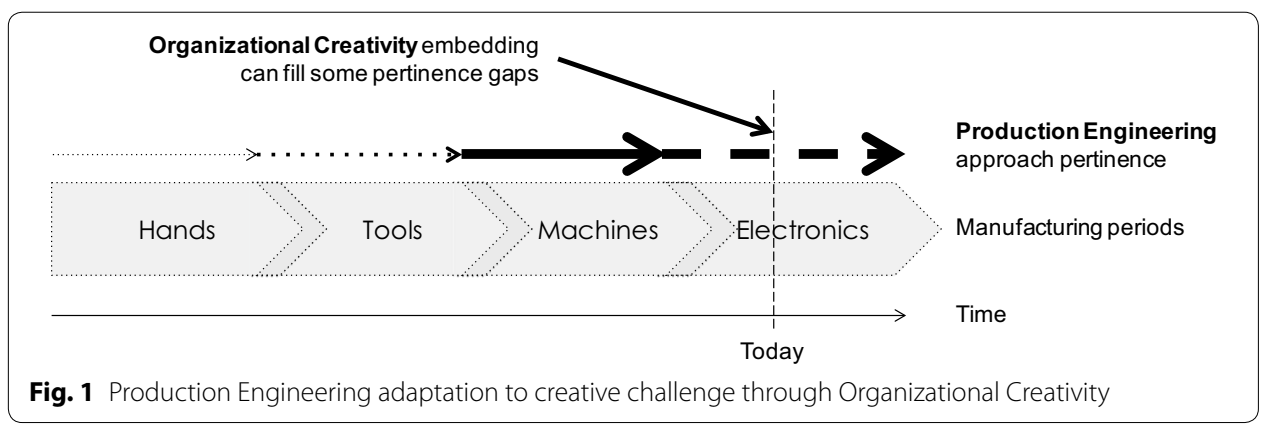


ideas for future studies linking classical production engineering subjects with the creative challenge are also presented.

\section{Organizational Creativity}

Organizational Creativity literature has been gaining strength mainly since the 1980s (Styhre and Sundgren 2005; Shalley and Zhou 2008), but it was based on earlier studies conducted in the field of Psychology and Management Theory. This interest can be marked from the publication of Hitt's article (1975), which advocated the importance of the role of creativity in all areas of organizations and also the importance of better use of creative talents available in the USA. Another mark that shows the growing interest in the study of Organizational Creativity, while also leveraging studies, was the creation of the Creativity and Innovation Management Journal, dedicated exclusively to studies dealing with theories and practices of creativity and innovation (Puccio and Cabra 2010).

Organizational Creativity differs from conventional studies of individual and group creative work as it takes into account the dynamics inherent to the organizational context. Some examples of differences that organizations have regarding these topics can be seen in studies on the influence of leadership, culture/climate, reward systems, size of organization, organizational environment, justice, environment, support, structure, resources, pressure, technologies, among others (Runco 2007; James and Drown 2012). In addition, there can be highlighted studies that deal with the issue of multi-level and cross-level creativity, i.e., with concepts that relate the influences that individual-grouporganization have with each other, and their permutations. The organizational creativity process may have to do with learning and adaptation capabilities of the organization, its product and modified versions of it, which can generate new commercial products, processes and innovations (Rickards 1999).

Another way to explain Organizational Creativity theory is by using the four fundamental aspects of creativity, the 4P's model-i.e., People, Processes, Products and environmental Pressures (Wallas 1926). Other models, such as Puccio and Cabra's (2010) also add Leadership as a separate fundamental aspect, forming the 4P + L model, which leads to organizational change (e.g., social change, personal change, innovations). Still others add Persuasion-creative people must change the way of thinking of other people and must be perceived as creative (Simonton 1990) - and Potential-prospects of possibilities still unfulfilled and subjective processes (Runco 2008)-reaching a 6P model (Kozbelt et al. 2010).

\section{People}

The creative person must show mental flexibility (i.e., tolerance for ambiguity; be able to suspend judgment; new ways of observing a situation, dealing with complex, unresolved situations, and do not accept simple solutions), can think of a lot of options, and should have the "helicopter" view, i.e., see the problems in a systematic way, analyzing big-picture (Albrecht and Albrecht 1987). Creative individuals tend to have high self-confidence, desire for independence, high tolerance for ambiguity, energy, playfulness, aggressiveness, flexibility, self acceptance, lack of concern with social constraints or opinion of others, sensitivity, introversion, and intuitiveness (Styhre and Sundgren 2005). 
Moreover, as creativity is a collective work, the creative person must possess skills to facilitate communication with other individuals, teamwork and the "sale" of the work. The literature lists, for example, intellectual courage to face apathy and rejection, as well as the ability to sell ideas as indispensable factors for this individual (Albrecht and Albrecht 1987), for it is through them that one can deal in a field of research and have their ideas accepted. At the same time, we must find a balance between features like carelessness or apathy and teamwork.

A person history can also influence in their creative results. For example, the family environment (promoting stimuli and intellectual values), independence as a child, formal education, the fact that the individual is whether or not a firstborn, the development of mental health and other factors can also impact capacity for creativity (Mumford and Gustafson 1988; Simonton 2012).

It should be noted that the influential factors on creativity are not equal for all areas of knowledge. Therefore, one has to know the context in which they want to develop or study creativity-e.g., concepts of the humanities disciplines are generally more vague, uncertain and ambiguous in relation to the social sciences. At the same time, the obsolescence of knowledge in fields of humanities is slower than that of the natural sciences, because each domain will have specific characteristics or rules that must be followed. Thus, individual characteristics that help creative work in a domain does not necessarily suits another, e.g., the natural sciences values order, stability, compliance, objectivity, realism, among other features, for a creative individual. In human sciences the flow, noncompliance, participation, imagination, purpose, autonomy, individualism, and other similar characteristics are valued (Simonton 2012).

Finally, in some of the literature the concept of creative person merges with the concept of the entrepreneur, considering entrepreneurship as the creation of a new product or process (Sawyer 2012). Entrepreneurship in this context would be a person's or group ability to make a creative product in the form of an innovation to the market (Bilton and Cummings 2014). The characteristics of entrepreneurial individuals appointed by the literature are similar to those of creative people (Chell 2008; Manimala 2009).

\section{Product}

The product is what comes out as a result of processes performed by people in an environment. It can be considered as creative when appropriate independent observers agree that it is creative (Amabile 1983). The creative product is not necessarily something physical, it can also be something intangible like a service, provided it is valuable and useful, and developed by individuals working together in a complex social environment (Woodman et al. 1993).

There are four fundamental concepts when performing suggestion and selection of ideas for creative products: fluency, flexibility, originality and elaboration (Guilford 1967; Guilford and Hoepfner 1971). Fluency refers to the amount of ideas generated without judgments regarding the quality. Flexibility refers to the number of categories of ideas referenced. The originality refers to statistical uniqueness of the idea that will potentially become a product (Shalley and Zhou 2008). The elaboration tells the degree of detail of the ideas generated, or the complexity of ideas. An idea that meets the four factors has high potential to become a creative product. The idea only becomes a creative product 
itself after being transformed into something more concrete that can be explained and accepted by the organization.

In addition to emerging from a group that wants to solve a problem, or create a product, ideas for a creative product can come from different places in the organization and so it is important that the organizational context is prepared and open to receive these ideas. Having employees in management position open to suggestions, as well as having devices that facilitate these suggestions (e.g., suggestion boxes, kaizen team etc.), will facilitate that ideas generated by employees from the outside of a problem-solving group can reach said group. It can be seen that, even without a specific group to solve a problem, an idea may emerge from the operation staff, solving a problem that was not even noticed or stressed by the organization.

\section{Process}

Having an environment conducive to creativity and uniting creative people is not enough for the emergence of creative products. Therefore, companies must invest in the study and improvement of its processes in order to help employees perform the creative processes more effectively using their skills (Puccio and Cabra 2010). There are several theories for modeling the creative process, each with distinctive features and similarities (e.g., Wallas 1926; Young 1940; Koestler 1964; Sawyer 2012, 2013; Csikszentmihalyi 2013). Most share certain characteristics: identify a problem or opportunity; seek and collect information; generate ideas; evaluate these ideas (Shalley and Zhou 2008). Furthermore, many of the creative processes from the literature focus on the importance of complementarity between the divergent and convergent activities. Both thought processes were identified by Guilford (1968) as important and unique pieces to solve creative problems. The first, divergent, is the thought that goes to different directions and generates a wide variety of ideas. The second transformation skill, the convergent thinking, involves the reorganization of information and the review of what is known in the light of new standards (Russ and Fiorelli 2010).

All the processes present in the literature have at least some dependence of the unconscious and a moment of enlightenment, which can take time and is considerably unpredictable. The first part of the process usually involves finding and defining a problem, by asking a question or looking at a challenge in a certain way that has never been explored. This part also involves gathering information as one seeks to have a significant amount of prior knowledge about the domain. Domain knowledge alone, despite being part of the process, is not enough, for the solutions may require concepts and information that come from other fields of knowledge, so one must also gather information that may be related but is not part of the Domain (Sawyer 2013). The second stage is usually described as incubation. Taking time for incubation, as well as giving the mind a moment to rest, can also be seen as a step toward "selective forgetfulness", i.e., free the mind of certain fasteners in the same solution or a traveled path (Burkus 2014). So, returning to the problem, which can be triggered by an event of chance, the mind is more open to new possibilities. The incubation effect has been recently demonstrated in laboratory experiments (e.g., Ellwood et al. 2009; Baird et al. 2012). The third stage is usually a convergent one, where one brings as many ideas as one can from the incubation period and try to combine them in unexpected ways. In the fourth stage, one has to 
consciously select and filter ideas from earlier stages and develop ways to explain them to the outside world. The final stage consists of the continuous improvement of the ideas presented, using external inputs to assess and improve them.

\section{Pressure}

Creativity in individuals, groups, organizations and processes depends on the arrangement and climate where they live (Kozbelt et al. 2010). Some of the differences to an environment may be individual-depending, for example, on history and personalitywhile others are general, such as freedom or the support and appreciation of originality (Amabile 1990). The research of organizational environment for creativity include positive and negative factors for creativity related to national culture, external environment, organizational culture, organizational structure, climate, and physical space (Puccio and Cabra 2010).

The very concept of creativity varies between different national cultures and, in addition, each region in a nation has a different development level and research field from others (Kaufman and Sternberg 2006). As an example, the way of thinking in Asia is different from the way of the Western culture, mainly because of its various philosophical basis, and therefore ways of creating are expected to be different between these cultures.

The external environment, in turn, relates to something outside the organization's control, but which affects its operation and is more changeable in the short and medium term than national culture (Isaksen et al. 2000-2001). The literature suggests that developments in the external environment can have direct impacts on creativity. For example, some case studies relate to legal challenges of establishing a new business in Latin America (De Soto 2000). Yet another points out that the conditions imposed by banks for research and development funding can undermine innovation (Inzelt 2003). Furthermore, some studies assess the impact that public policies to encourage creativity and innovation-legal support, or eliminating processes bureaucracies for fundraising, or the integration between academia, industry and the public sector-may have on organizational creativity (e.g., Forbes and Wields 2002; Chung 2003; Kao 2007; Edquist and Hommen 2008).

Organizational culture relates to feelings, norms, values and 'shared beliefs' that lead to actions in the organization (Alencar 2012). In short, how things are done in the workplace, or 'how things work around here' (Lundy and Cowling 1996). This can impact in many ways on the creative capacity of the organization. For example, the vision and mission of the organization can take, or not, a strategy that specifically focus on the development of new products; culture will influence the organizational structure, impacting the creative process; support mechanisms, such as rewards and recognition, as well as allocation of resources, may be influenced by the cultural values; freedom of communication; and behaviors encouraged-the creative processes may require opening to failure and risks, conflict management, among others (Martins and Terblanche 2003). The literature has brought several cases describing the culture of known creative organizations or innovative (e.g., Ferraz 2002; Blecher 2005; Elgin 2005; Burrows 2008; Hargadon 2008; Amabile et al. 2014; Catmull and Wallace 2014).

Organizational structures concern the hierarchy and command lines, communication and authority of the organization, whether formal or informal. The size and age of the 
organization impact on their ability to be creative and innovative. The larger the organization, the greater the amount of technological and administrative innovations, however minor their agility and their ability to innovate when there are environmental changes (Christensen 1997; Rogers 2003). As of age, the more mature an organization, more its rules are rooted and, if these standards were not favorable to creativity and innovation, the greater the difficulty to innovate and adapt (West and Richter 2008). The literature also brings models of organizational structures to support the activities of innovation and creativity. As an example, an interesting model proposing what it calls "deep structures" can be found in Dougherty and Tolboom (2008).

Climate is related to the perception that workers have about the organization, being changed by internal or external factors, and is opposed to the organizational culture for its unstable nature, that is, culture is complex and deep and relates to the values rooted in the company, while the climate can be altered by factors such as news, events and even rumors (Fleury and Sampaio 2002). This process also has a strong relationship with people's motivation; need to achieve self-realization and respecting diversity and individuality (Chiavenato 2008).

The culture and organizational climate may have ramifications from simple to more complex levels of the company. By encourage a culture of released humor, for example, organizational environment improves and organizational creativity increases while controlling mood has the opposite effect (Lang and Lee 2010). Another example is to make a physical environment conducive to innovation, with ergonomics that incentive it, which also increases the creative performance (Dul and Ceylan 2011). The culture and organizational climate are closely related to leadership. The leader of is a key factor in the work environment focused on creativity, being positively related to creativity of subordinates and their responses (Amabile et al. 2004).

In the literature there are several models that deal with the organizational climate. Ekvall (1983), for example, highlights ten dimensions related to the creative climate: dynamism; challenge; freedom; trust and openness; support for ideas; conflicts; debates; time for ideas; playfulness and mood; and risk appetite.

Amabile and Gryskiewicz (1989) developed a tool, work environment inventory (WEI), in order to identify and measure environmental factors that impact on creativity. This tool was then evolved to the KEYS model which measures in ten dimensions the management practices, organizational motivation, resources and results (Amabile et al. 1995; Amabile 2010): freedom (i.e., sense of control, decision of what work to do and how to do it); work challenge (i.e., feeling of working in challenging and important tasks); encouragement of management (i.e., a boss who is a good example, which encourage the group, demonstrate confidence in the group, set appropriate goals and values individual contributions); support for the working group (i.e., group with varied skills, good communication, openness to ideas, intra-group constructive challenges, commitment to work, trust and mutual help); organizational encouragement (i.e., culture with righteous judgment of ideas, rewards and recognition for creative work, incentive mechanisms to develop new ideas and a shared vision); lack of organizational impediments (i.e., not prevent creativity by internal political problems or too harsh criticism of new ideas, destructive internal competition, very high risk aversion and encouraging the status quo); have sufficient resources (i.e., access to the appropriate resources, including 
funds, materials, facilities, and information); realistic workload pressure (i.e., no extreme time pressure, unrealistic expectation of productivity, and distractions). The results measured by the tool are creativity itself-if there is unity of creativity requirement and if people believe that actually produce creative work-and productivity-efficiency and effectiveness of the unit.

Such studies have been also done in Brazil with local companies (Bruno-Faria and Alencar 1996; Alencar and Bruno-Faria 1997; Alencar et al. 2003; Alencar 2012), resulting in the creation of Climate Indicators for Creativity (Bruno-Faria and Alencar 1998; Bruno-Faria 2014). Ten categories were found with favorable factors of creativity: challenges that require creative ideas; freedom and autonomy; management support; organizational structure with flexible rules, limited hierarchy and decentralized power; organizational support; well prepared physical environment with lighting, furniture, adequate space and ventilation; wages and adequate benefits with incentives for innovation; technological and material resources; training to develop the creative and innovative potential; and work team support, with good interpersonal relationships, trust and dialogue.

These same studies show that the most prominent obstacles to creativity in Brazil are the organizational structure-rigid, bureaucratic, with centralized power and excessive hierarchy-managers who are not receptive to new ideas and products, organizational culture averse to risk, bad relationships at work-frequent conflicts, and lack of dialogue and confidence-blocking new ideas and excessive amount of tasks with too limited time.

In addition to presented ones, there are other research in the area that are worth mentioning that have many aspects in common with those previously stated (e.g., Cummings 1965; Rickards and Bessant 1980; Siegel and Kaemmerer 1978; Basadur 1987; Anderson and West 1998). Job security (VanGundy 1987) and the sense of fairness as positive factors and the envy and jealousy as negative factors (Cabra et al. 2005) are also noted.

\section{Conceptual models}

According Shalley and Zhou (2008), there are two main conceptual models that guided organizational creativity: Amabile (1988, 1996) and Woodman et al. (1993). Besides them, one may also include Ford (1996), evolving the existing conceptual models, and the criticism developed by Unsworth (2001) regarding studies conducted in the area.

Amabile $(1988,1996)$ classify factors affecting creativity into three main components: skills relevant to the domain-knowledge and expertise-relevant processes for creativity-skills and strategies for creativity and creative tasks experience-and motivation to work. The first factor is affected by formal and informal training, as well as motor skills, cognitive and individual perception. The second factor concerns the knowledge to produce creative ideas, cognitive styles and working styles for the production of ideas. The third is subdivided into two: intrinsic motivation, coming from personal interests, involvement, curiosity and satisfaction; and extrinsic motivation, from external sources to the task itself. The model proposes that, generally, intrinsic motivation is vital for creative activity while extrinsic would be antagonistic.

However, some extrinsic motivators may work synergistically with intrinsic motivators if they have a high level of motivation (Amabile 1993). This can occur when extrinsic 
motivators are in service of intrinsic ones, in other words, when they reinforce the feeling of competence without undermining self-determination (e.g., feedbacks that inform on how to improve a competence, as well as those that confirm the competence). Another mechanism is the correspondence between work-motivation cycles, where creative performance improves if the correct motivation corresponds to a particular stage of the working cycle (creative process). In this case, it is emphasized that the intrinsic motivations will have greater importance in the presentation steps of the problem and the generation of ideas, while extrinsic motivations have greater alignment with the stages of validation and communication of the idea.

Woodman et al. (1993) develop an interactional approach, sharing the creative process in individual, group and organizational levels. The model describes the interactions between these levels with each other and with the external environment. Individual creativity is seen as a function of antecedent conditions-history-individual knowledge, personality, intrinsic motivation and cognitive ability/style. In addition, the individual also suffers social influences from the groups one is into, and contextual influences on the part of the organization. The group level is a function of its composition, its specific characteristics and its processes. In addition, the group also suffers contextual influences from the organization and receives the responses of individual social influences. The last level, the organizational one, is a function of group creativity and contextual influences from the external environment. The output of this model is the creative result of the organization.

Ford and Ford (1987) coined the term "behavior episode" for slices of life that make up the experience of an individual, which are directed to a desired goal, having a beginning, middle and an end. These episodes can end in three ways: when the goal is met, when the person is distracted by another objective, or when it is believed that a goal is unattainable. According to the author, these episodes represent the natural interactions of variation, selection and retention processes that define creativity and commonplace behavior. In this design, while the habitual behavior is attractive, even in an enabling environment for creativity, individuals will tend to remain in routine (Ford 1996).

In this model, creative action is the result of the combination of three factors: sense making (being prone to finding problems), motivation-subdivided into goals, such as creativity, independence and results; receptivity beliefs, like the belief of reward for creative actions; capacity beliefs, like the confidence in one's creative ability; and emotionsand, the last factor, is the knowledge and skill-subdivided into knowledge related to domains (miscellaneous experiences); behavioral skills, such as communication skills; and creative thinking skills, such as association skills and divergent thinking. It also emphasizes that the creative action can have an impact in areas beyond the organization, like the institutional environment and the market as a whole.

Unsworth (2001) criticizes earlier works, defending that there is not only one type of creativity, but four. Her typology of creativity in problem solving takes into account basic questions: "Why?"-the motivation behind the engagement-and "What?"-the necessary degree of searching for the problem. The model sets two types of problems: open, where participants must find, invent or discover the problem or parts thereof; and Closed, which require changes to specific and well understood situations. It also defines two forms of motivation (drivers) for engagement: external, where the situation requires 
certain behavior; and Internal, where individuals wish to get a result and want to be creative.

For a closed problem with external motivation, there is Responsive creativity, that being one in which solutions are required for a specific issue (e.g., a group brainstorming assembled to perform in a given project). For a closed problem with internal motivation, there is the Contributory creativity where there are voluntary contributions to a specific problem (e.g., open innovation). For an open problem with external motivation, there is Expected creativity, which requires solutions to problems that must be discovered (e.g., the process of a Design Thinking consultancy can fit here). Finally, to an open problem with internal motivation, there is Proactive creativity where a voluntary solution is developed to problems that had not yet been discovered (e.g., an unexpected suggestion that solves an unknown problem).

In addition to the listed contributions, it should be noted that there are other relevant studies that develop models or parts of models for organizational creativity (e.g., Drazin et al. 1999; Mumford 2000; Mainemelis 2001; Perry-Smith and Shalley 2003; Elsbach and Hargadon 2006; Hargadon and Bechky 2006).

\section{Organizational Creativity and Production Engineering}

Production Engineering is the discipline that studies, design, manages and acts upon productive systems. A University course has many subjects that focus on aiding production engineers understanding of all aspects of a factory or a service, but, as stated earlier, these subjects were developed with an industrial mindset and therefore lack proper tools for operating and managing creative organizations. This doesn't mean that production engineers don't work or consult for creative companies, but rather that one accepting such a challenge is not being well prepared by our colleges today, and is not being fully supported by academia. This lack of preparation might lead to two outcomes: a timeconsuming effort to develop new tools that are focused at a specific organization and may never be known by the engineering community or further developed; or a seemingly effortless miss adaptation of an industrial tool to a problem that it wasn't designed to assess, leading to possibly bad results. For this paper, we use the Federal University of Rio de Janeiro (UFRJ) curricula, the first and one of the most prominent engineering Universities in Brazil, in order to seek disciplines that can be developed using inputs from the organizational creativity literature and could be encouraged in classroom.

In this section, most of the subjects and topics from the UFRJ course that deals with core Production Engineering topics-that is, we won't consider for this paper basic disciplines, such as Calculus, Statistics, Physics and Chemistry-are presented. At the same time, we show if and how some topics from organizational creativity could be inserted in today's subjects' contexts as a mean to broaden what is covered by each one of them. These suggestions are shown in Table 1 in order to facilitate the reading and understanding.

As one can see, there are many Organizational Creativity topics that could be approached in the core disciplines of the Course, contributing to reduce the knowledge gaps of the Production Engineering professionals that graduates on UFRJ when working on creative organizations. 


\section{Organizational Creativity and the Entertainment Industry}

Entertainment, as highlighted by Vogel (2011) is everything that stimulates, encourages or creates a condition of pleasurable fun; coming from the Latin term "tenare", it touches the soul. From the Production Engineering Course perspective, the organization that dedicates to producing entertainment is a system with a lot of creative tasks, in addition to others that are already automated or standardized. Figure 2 follows from Voguel's definition.

Table 1 Subjects and topics from the UFRJ Production Engineering Course

\begin{tabular}{|c|c|}
\hline Discipline & Organizational creativity additions \\
\hline \multicolumn{2}{|l|}{ Methods engineering } \\
\hline $\begin{array}{l}\text { Problem-solving methods. Movements studies. } \\
\text { Recording techniques and work analysis timing } \\
\text { techniques. Evolution of work in the factory organ- } \\
\text { ization. Healthy work environment. Analysis and } \\
\text { project work situations: antropometry, information } \\
\text { and control devices. Cognitive aspects. Cognitive } \\
\text { aspects of work: prescribed and real }\end{array}$ & $\begin{array}{l}\text { The study of which method is the most productive for } \\
\text { creative tasks could be of great value. It fits in the } \\
\text { Process category, as one should study the many tech- } \\
\text { niques that are already presented by the literature (e.g., } \\
\text { Osborn 1953; Gordon 1961; Cooperrider and Srivastva } \\
\text { 1987; Debono 1999; Dorst 2011). The student could } \\
\text { try all these tools (e.g., brainstorming, } 6 \text { thinking hats, } \\
\text { Appreciative Inquiry, design thinking, Synetics, TRIZ) } \\
\text { and could measure for each problem situation witch } \\
\text { one would bring the best results }\end{array}$ \\
\hline \multicolumn{2}{|l|}{ Work engineering } \\
\hline $\begin{array}{l}\text { Workplace safety. Motivational factors. Ergonom- } \\
\text { ics. Safety standards in industrial environments. } \\
\text { Analysis of jobs }\end{array}$ & $\begin{array}{l}\text { Studying the task and ergonomics of the creative worker. } \\
\text { It fits in the people and pressure categories, as indi- } \\
\text { vidual characteristics should be studied as well as the } \\
\text { physical and cognitive environment that surrounds the } \\
\text { creative worker }\end{array}$ \\
\hline
\end{tabular}

Introduction to economics

Evolution of economic science. Different schools of thought: pre-scientific stage; commercialism of the modern schools. Concept: economic problems and human need. Direct and indirect exchanges: circular flow of the economy. Government: its economic functions. Private companies: legal form and financing. Social accounting: aggregates of measures: the classic design and the Keynesian conception. Currency: different financial institutions, commercial banks. Monetary policy and fiscal policy: monetarists and Keynesians. External sector: balance of payments. Notions of microeconomics: market and prices. The consumer and demand utility. Production and cost. View alternative costs. Market structure

Product design

Phases: product development. Value analysis. Market aspects. Methodology of product development. Technical presentation of the product design

This discipline is not directly related to the organizational creativity topics discussed in this paper

We believe though that the economics foundation given by this discipline impacts further understanding of the creative industries market dynamics. This knowledge could be very useful for creativity jobs practitioners, and, as a topic, it may be further deepened if there was a discipline dedicated to Creativity Engineering

Information engineering

Introduction: information engineering; models of development of information systems; strategic planning information; Data modeling; modeling activities; hierarchical organization and models balancing; construction, implementation and system maintenance

This discipline is intimately connected with the organizational creativity discussion. The design of a product is per se a creative task well deserving of a methods study itself. For this discipline, the product and process categories are at hand. The design of a creative product should obey fluency, flexibility, originality and elaboration rules. Also, the creative process and the design thinking technique (e.g., Dorst 2011) are also powerful contributions

This discipline is not directly related to the organizational creativity topics discussed in this paper

We should note though that developing an IT system is a creative task that can be aided by creativity process 
Table 1 continued

\begin{tabular}{l} 
Discipline \\
\hline Industrial facilities \\
Lumino-technical. Electrical installations. Sanitation. \\
Hydraulic. Storm water facilities. Gas facilities. \\
Collection and treatment of water. Treatment of \\
industrial wastewater. Cooling. Air conditioning \\
and heating. Special facilities (boilers, compressed \\
air, liquid nitrogen etc.)
\end{tabular}

Organization and evaluation of labor

Concepts and basics. Work, work organization and job evaluation. Evolution of the organization of work in capitalist society. Work studies in Brazil. Work organization of schools in the twentieth century. Notions and applications. Evaluation of the work. Forms of hand labor pay

\section{Engineering economics}

Initial concepts: interest, fees and forms of capitalization. Calculation of interest: simple, compound and continuous regimes. Capital equivalence: present value and rate of return (calculation method). Series of payments and compound interest factors. Repayment of loans: price systems, sac and indexation. Cash flow: Investments: "payback" present value, rate of return and annual cost

Operational research

Introduction to OR: initial history and development. Modeling OR Linear Programming: Modeling, the simplex method, duality, use of computer packages. Models allocation and transportation. Introduction to game theory. Modeling graphs. Problems with graphs in operations research. Models and dynamic programming algorithms. Queuing models. Inventory models

Industrial psychology and sociology

History of the discipline and the new approaches required by the new industrial paradigm. Principles of management motivation and learning. Group dynamics, synergy in teams, structuring the relationship between teams. The roles of Production engineers in the emergence of a new organizational culture

Quality control

Total quality management. Audit and quality. Quality tools. Quality costs

\section{Organizational creativity additions}

The study of facilities is paramount for the well development of creative problem solution. This discipline deals with the Pressure category, as Creativity in individuals, groups, organizations and processes depends on the arrangement and climate where they live (Kozbelt et al. 2010). The physical environment has a direct impact on creativity and should be well studied. Organizations recognized today that the classic physical environment, mechanist, is not suitable for creative processes or innovation (Puccio and Cabra 2010). Some companies such as IDEO, have already approached practices of freedom to employees to decide on the physical environment (Kelley and Littman 2001). Technological devices that support innovation and offices or innovation labs are also possible solutions that have been used by organizations (Magadley and Birdi 2009)

This discipline is directly related to the study of the creative market and the Conceptual Models for creativity. On one hand it could study the dynamics of employee-employer relationship in creative industries and how are power balances of this economy. On the other hand it could study the many models of creativity and its motivations in order to understand, evaluate and organize the needs of creative labor

This discipline is not directly related to the organizational creativity topics discussed in this paper

We believe though that the financial foundation given by this discipline could be very useful for creativity jobs practitioners. Understanding contracts and fund raising are some topics much needed in creative industries

This discipline is not directly related to the organizational creativity topics discussed in this paper

We believe though that the ability to solve complex problems given by this discipline could be very useful for creativity jobs practitioners, that are often faced with such complexities

This discipline is directly related with the organizational creativity discussion. It fits in the Pressure and Conceptual Models category, as it should study the organizational internal environment for creativity. The climate, culture, leadership and motivations are all topics for this discipline

This discipline is not directly related to the organizational creativity topics discussed in this paper, as a statistical control of a creative process is too complex or impossible. New ways to control quality could be studied specifically for creativity processes 
Table 1 continued

\begin{tabular}{l} 
Discipline \\
\hline Facilities planning \\
Notions of physical arrangement. Design method- \\
ology. Infrastructure for physical arrangement \\
project. Hygiene aspects and safety applied to the \\
planning of facilities
\end{tabular}

\section{Organizational creativity additions}

This discipline is directly related to the environmental Pressures and the Process of creativity. The influence of the physical environment in the creative process is a branch of study still in development, since during a long time it has been neglected by the academic literature (Amabile 1996; Kristensen 2004; Haner 2005). Furthermore, it suffers from methodological problems in many of its experiments and published articles (Boutellier et al. 2008) due to its difficult nature of admeasurement. Still, it is known that the environment has a strong impact on creative processes (Stokols et al. 2002) and has severe negative impact when it is not addressed in the planning of the organization (Alencar and Bruno-Faria 1997)

Computer integrated manufacturing

Integration. CIM models. Case studies

Quality management

Total Quality Control in the Company. Statistical Process Control (SPC). ISO 9000 standards

Production planning and control

History. Definitions and concepts in different structures and industrial segments: organizations and major functions. Project management. General capacity planning. Balancing lines. Demand forecasting. Master planning. Inventory control. Manufacturing resources planning (MRP II). Distribution Requirements Planning (DRP). Sequencing operations. Control of factory floor by simulation. Computer integrated manufacturing (CIM). Japanese industrial techniques (JIT). Optimized production technology (OPT). Examples and experiences from the frontiers of knowledge

Human resource management

History, basic principles and constraints of the management of human resources in Brazil. The planning and implementation of the management of human resources in Brazilian industries.

Strategic planning

Unfortunately we could not find the detailed topics of this subject

Business process engineering

Production Engineering processes paradigm. Management and Business Process Engineering. Business Concepts; Process modeling. Analysis and improvement of business processes. Implementation of business processes. Engineering developments and management of business processes. Case studies in process engineering. Presentation and discussion of specific processes modeling software

This discipline is indirectly related to the creative Process, given one must manage or develop IT tools to support it-e.g., electronic brainstorming; group conference tools

This discipline is related to the Process category of this paper. Developing methods to manage the processes in order to reduce wasted time and resources is a much needed field of research for creative organizations

This discipline is related to the Process category of this paper. Knowing how to plan the innovation pipeline and controlling the creative processes is paramount for healthy creative organizations

This discipline has a direct link with the management of creative people and can carry out research on the best way to create an enabling environment for creativity, in addition to studying better ways for remuneration, training and selection of people for creative tasks

This course could explore the development of strategies in organizations with a focus on creativity processes. It is known that the entire organization should be aligned with the strategy, so it makes sense that students learn how to develop it the right way for fostering creativity in organizations

This course could explore better ways to map the creative processes, presenting students with models that already exist and encouraging test the relevance of these models for real life scenarios 
Table 1 continued

\begin{tabular}{|c|c|}
\hline Discipline & Organizational creativity additions \\
\hline \multicolumn{2}{|l|}{ Projects and concurrent engineering management } \\
\hline $\begin{array}{l}\text { Unfortunately we could not find the detailed topics } \\
\text { of this subject }\end{array}$ & $\begin{array}{l}\text { This course could approach project management } \\
\text { practices in organizations with a focus on creativity. } \\
\text { What is the best way to manage a project whose aim is } \\
\text { a creative product? }\end{array}$ \\
\hline
\end{tabular}

Entertainment industry today is very powerful. According to recent data from SEBRAE, ${ }^{1}$ the entertainment market is expected to reach 71 billion dollars in revenues in Brazil by 2017. The forecast is based on the unique position the country has gained internationally because of the great events that it will receive. The study also pointed out that the most promising area in the national scene involve access to the internet, advertising and TV shows that are responsible for $60 \%$ of the entertainment industry's sales in the country. This industry presents high innovation potential, offering great job opportunities for Production Engineers that are able to deal with creative processes.

Kamel (2006) points out that the national entertainment production needs to link technological and social development strategies, and that it has to be directed to activities that value local culture. We have two critical facets of entertainment situation in Brazil: it is not taken as seriously as it should be in order to generate economic growth and increased importance of Brazil in the international arena; and more, it is not democratic, there is no real concern to involve the people as a whole, giving easier access, investing heavily in the dissemination of culture. We live two different realities, one where the entertainment industry is booming, but most of the funds are dominated by big media corporations and event planning organizations, and another one where independent producers and small companies that want to bring local cultures to a broader audience have to struggle and compete a lot in order to get some funding-mostly directly or indirectly financed by the government.

Production Engineering tools may prove helpful for a plethora of scenarios. Big media conglomerates, for example, have many needs that are closely related to management functions and production planning. As a big company, they may have all the classical problems studied by production engineers such as "silo" culture, logistics complexity, lack of good communication, need for process modeling, low systemic comprehension by the staff, complex facilities planning and building problems, and others. Small companies may have other problems that production engineers may aid, like short-term vision, budget problems, lack of well-studied processes, need for managerial systems, poor HR processes, and others. It is undisputed that Production Engineering is a discipline that is much needed in the entertainment industry. The problem being that these engineering tools were all developed with industrial demands in mind, with all the limitations pointed out in the beginning of this paper. The nature of entertainment industries tasks is potentially different from industrial ones, there is greater need of freedom and flexibility, and measuring quality for an intangible product is a much harder task. Trying to

\footnotetext{
1 The abbreviation for 'Brazilian Support Service for Micro and Small Enterprises', SEBRAE is a Non-Governmental Organization widespread through all Brazilian territory, which aims to assist the development of micro and small enterprises, stimulating entrepreneurship in the country.
} 


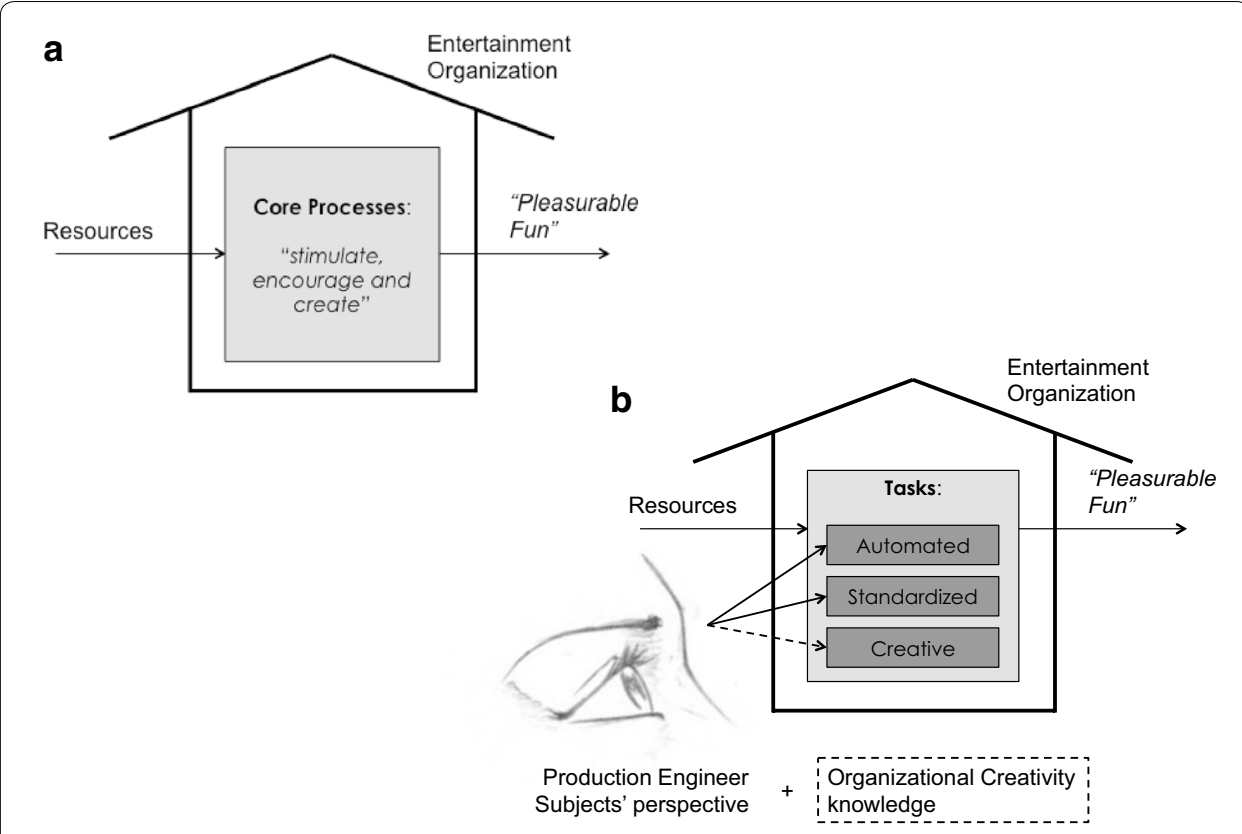

Fig. 2 Production Engineering Course subjects' perspective. a shows an outsider view of an Entertainment Organization, like a "black-box". b shows the Production Engineer's perspective, following Vogel's definition

apply industrial tools and studies to the entertainment industry without prior adaption studies end up leading to results that may be even worse than the situation that is being solved.

Entertainment Engineering problems are real and, as one can see in this simple example, can have dire consequences if done incorrectly. This subject is a part of the Production Engineering curricula in UFRJ, but is still scoffed upon by many other Universities and, besides being an isolated matter; it even faces opposition from some members inside UFRJ, mainly for being too "distant" from classical engineering fields. In this subject the student learns about the importance of entertainment activities in modern economies, its relations with education, art and culture, and social division of labor. Cases studies are presented for a diverse set of industries, such as TV, cinema, music industry and shows, printing plant and publishing, sports, tourism, theater, carnival and other popular events; presenting projects in real situations, taking into account opportunities, legislation, methodologies and documentation, as well as presenting real work scenarios in entertainment activities.

Despite the obstacles presented by some scholars, Entertainment Engineering is experiencing a slow but steady growth in Brazil in the last few years, especially in the form of articles and monographs, showing a demand that, although badly assessed by local Universities, can encourage students to go the extra mile and develop solutions of their own, contributing to the Production Engineering body of knowledge (Nunes 2014). Entertainment Engineering deals mainly with enterprises with highly creative activities and therefore is eligible for a quick-win when using organizational creativity as shown in this article. It is our belief that this discipline has the potential to be the first to adopt inputs 
that the study of creativity can offer, with greatest benefits. By studying the conceptual models of creativity-and the many types of creative through the 4P point of viewEntertainment Engineering can make the first step toward uniting the many Production Engineering industrial subjects with such models and, at the same time, applying these jointly developed concepts to real world problems on highly creative scenarios. We believe that this articulation would only bring benefits to Entertainment Engineering, as it could show even more its key role in todays challenges and how much it is needed for today's Production Engineering.

\section{How it all fits together: Creativity Engineering}

As one can see, organizational creativity and Production Engineering could be more tightly connected than one might expect without a closer look. In this paper, we hope to have aroused curiosity and interest on engineers and creativity scholars and practitioners alike, showing the relation to each course subject. We state that the entertainment industry may be a relevant step towards showing the importance of the link between these two worlds, by applying concepts to real world, highly creativity demanding, organizations. Creativity and entertainment walk side by side, but production needs are also a big part of this business, sometimes-needing high throughputs, high quality and facing strict budget restriction. It is a situation that is very much favorable for the practice and management by production engineers. At the same time, engineers have much to learn from their artistic and creative counterparts.

We believe this may be a first step, but there are other needs that should be assessed. One of them is that not only entertainment industries face creative challenges. There are many economy sectors that seek to improve their creative production, but face methodological barriers, like education, R\&D, IT development, consulting and many others. We see two scenarios for the development of a creativity production mindset and ability for new engineers. One way to do it is by encouraging the development of tools and studies in the classical course disciplines, whereas a professor that is the specialist in an area of knowledge expands his abilities to also teach about creative organizations in a particular topic. The other way we believe could bring great results is the development of a new discipline, called Creativity Engineering. This discipline could be taught for students that are motivated by this theme and would join contents from all classical topics with a focus on creative activities, stimulating field works in organizations that perform such activities.

We have also some suggestions for future studies. One is the further development of creativity studies by professionals and students of each Production Engineering academic subject. A person that is a specialist in a field of knowledge is the best one to enrich this kind of debate. We should note that some effort by Barradas and Cardoso (2014) is already being done to articulate the study of Facilities Planning and Organizational Creativity. Ultimately, although some evolution has been made to link Production Engineering and Organizational Creativity, there is still much to be planned and discussed for it to become a true addition to Universities' graduation and post-graduation courses. There is a need to promote this union in a broader sense, and to really make the difference in the professional life of the engineers being trained. 


\section{Authors' contributions}

The present paper resulted from the MSc research of GBB under the supervision of VCC in COPPE/UFRJ. For this paper, while GBB has performed an extensive research on Organizational Creativity and Entertainment Engineering, VCC supervised him and, as head of UFRJ's Production Engineering Department, provided deep understanding of the Production Engineering course. All authors read and approved the final manuscript.

\section{Competing interests}

The authors declare that they have no competing interests.

Received: 21 June 2016 Accepted: 13 July 2016

Published online: 22 July 2016

\section{References}

Albrecht K, Albrecht S (1987) The creative corporation, 1st edn. EUA. Dow Jones-Irwin, Homewood, Illinois

Alencar EMLS (2012) Creativity in organizations: facilitators and inhibitors. In: Mumford MD (ed) Handbook of organizational creativity, 1st edn. Elsevier, San Diego, pp 87-111

Alencar EMLS, Bruno-Faria MF (1997) Characteristics of an organizational environment which stimulate and inhibit creativity. J Creat Behav 31:271-281

Alencar EMLS, Fleith DS, Martinez A (2003) Obstacles to personal creativity between Brazilian and Mexican university students: a comparative study. J Creat Behav 37:179-192

Amabile TM (1983) The social psychology of creativity, 1st edn. Springer, New York

Amabile TM (1988) A model of creativity and innovation in organizations. In: Staw BM, Cummings LL (eds) Research in behavior. JAl, Greenwich, pp 123-167

Amabile TM (1990) Within you, without you: the social psychology of creativity, and beyond. In: Runco MA, Albert RS (eds) Theories of creativity, 1st edn. Sage, Newbury Park, pp 61-91

Amabile TM (1993) Motivational synergy: toward new conceptualizations of intrinsic and extrinsic motivation in the workplace. Hum Resour Manag Rev 3(3):185-201

Amabile TM (1996) Creativity in context. Westview, Boulder

Amabile TM (2010) KEYS to creativity and innovation: user's guide. Center For Creative Leadership, Greensboro

Amabile TM, Gryskiewicz N (1989) The creative environment scales: the work environment inventory. Creat Res J 2:231-254

Amabile TM, Taylor S, Gryskiewicz ND (1995) Technical manual for KEYS: assessing the climate for creativity. Center for Creative Leadership, Greensboro

Amabile TM et al (2004) Leader behaviors and the work environment for creativity: perceived leader support. Leadersh Q 15(1):5-32

Amabile TM, Fisher CM, Pillemer J (2014) IDEO's culture of helping. Harv Bus Rev 92(1):54-61

Anderson NR, West MA (1998) Measuring climate for work group innovation: development and validation of the team climate inventory. J Organ Behav 19:235-258

Baird B et al (2012) Inspired by distraction: mind wandering facilitates creative incubation. Psychol Sci 23(10):1117-1122

Barradas GB, Cardoso VC (2014) Uma Proposta para Disciplina de Planejamento das Instalações em Organizações Criativas. XLII Congresso Brasileiro de Educação em Engenharia - COBENGE, Anais

Basadur M (1987) Needed research in creativity for business and industrial applications. In: Isaksen SG (ed) Frontiers of creativity research: beyond the basics. Bearly, Buffalo, pp 390-416

Bilton C, Cummings S (2014) Handbook of management and creativity, 1st edn. Edward Elgar, Cheltenham

Blecher N (2005) Ideias que viram dinheiro. Exame 39:22-28

Boutellier R et al (2008) Impact of office layout on communication in a science-driven business. R\&D Manag 38(4):372-391

Bruno-Faria MF (2014) Indicators of the climate for creativity in the workplace. In: Alencar EML, Fleith DS, Bruno-Faria MF (eds) Theory and practice of creativity measurement, 1st edn. Prufrock Press, Waco

Bruno-Faria MF, Alencar EMLS (1996) Estímulos e barreiras à criatividade no ambiente de trabalho. Rev Adm 31:50-61

Bruno-Faria MF, Alencar EMLS (1998) Indicadores de clima para a criatividade: Um instrumento de medida da percepção de estímulos e barreiras à criatividade no ambiente de trabalho. Rev Adm 33:86-91

Burkus D (2014) The myths of creativity. Jossey-Bass, San Francisco

Burrows P (2008) Bezos on innovation. BusinessWeek. Acessado em: 25 Sep 2014. http://www.businessweek.com/ stories/2008-04-16/bezos-on-innovation

Cabra JF, Talbot RJ, Joniak AJ (2005) Exploratory study of creative climate: a case from selected Colombian companies and its implications on organizational development. Cuad Adm Bogotá Colômbia 18(29):53-86

Catmull E, Wallace A (2014) Creativity Inc:: overcoming the unseen forces that stand in the way of true inspiration. Random House, New York

Chell E (2008) The entrepreneurial personality: a social construction, 2nd edn. Routledge, London

Chiavenato I (2008) Gestão de Pessoas: o novo papel dos recursos humanos nas organizações, 3rd edn. Campus, Rio de janeiro

Christensen C (1997) The innovator's dilemma: when new technologies cause great firms to fail, 1st edn. Harvard Business Review Press, Boston

Chung S (2003) Innovation in Korea. In: Shavinina LV (ed) The international handbook on innovation. Pergamon, Oxford, pp 890-903

Cooperrider DL, Srivastva S (1987) Appreciative inquiry in organizational life. Res Org Change Dev 1:129-169 
Csikszentmihalyi M (2013) Creativity: the psychology of discovery and invention, 1st edn. HarperCollins, New York (original de 1996)

Cummings L (1965) Organizational climates for creativity. Acad Manag J 8(3):220-227

De Soto F (2000) The mystery of capital: Why capitalism triumphs in the West and fails everywhere else. Bantam Press, London

Debono E (1999) Six thinking hats, 2nd edn. Back Bay, Boston

Dorst K (2011) The core of 'design thinking' and its applications. Des Stud 32:521-532

Dougherty D, Tolboom JN (2008) Creative organizing to enable organizational creativity. In: Zhou J, Shalley CE (eds) Handbook of organizational creativity, 1st edn. Taylor and Francis Group, New York, pp 237-261

Drazin R, Glynn M, Kazanjian R (1999) Multilevel theorizing about creativity in organizations: a sensemaking perspective. Acad Manag Rev 24:286-307

Dul J, Ceylan C (2011) Work environments for employee creativity. Ergonomics 54(1):12-20

Edquist C, Hommen L (eds) (2008) Small country innovation systems: globalization, change and policy in Asia and europe. Edward Edgar, Cheltenham

Ekvall G (1983) Climate, structure and innovativeness in organizations: a theoretical framework and an experiment. The Swedish Council for Management and Organizational Behaviour Report, vol 1. FA rådet, Stockholm

Elgin B (2005) Managing Google's idea factory. BusinessWeek, pp 88-90

Ellwood S et al (2009) The incubation effect: hatching a solution? Creat Res J 21(1):6-14

Elsbach KD, Hargadon AB (2006) Enhancing creativity through "mindless" work: a framework of workday design. Organ Sci 17:470-483

Ferraz E (2002) O que faz com que algumas empresas sejam brilhantes na arte de inovar. Exame 36:47-61

Fleury MT, Sampaio J (2002) Uma Discussão Sobre Cultura Organizacional. In: Fleury MT (ed) As Pessoas na Organização, 1st edn. Editora Gente, São Paulo, pp 283-294

Flusser V (2007) O Mundo Codificado, 1st edn. Cosac Naify, São Paulo

Forbes N, Wields D (2002) From followers to leaders: managing technology and innovation in newly industrializing countries. Routledge, London

Ford CM (1996) A theory of individual creative action in multiple social domains. Acad Manag Rev 21(4):1112-1142

Ford ME, Ford DH (1987) Humans as self-constructing living systems: putting the framework to work. Erlbaum, Hillsdale Gordon WJJ (1961) Synectics: the development of the creative capacity, 1st edn. Harper \& Row, New York

Guilford JP (1967) The nature of human intelligence. McGraw Hill, New York

Guilford JP (1968) Intelligence, creativity and their educational implications, 1st edn. Knapp, San Diego

Guilford JP, Hoepfner R (1971) The analysis of intelligence. McGraw Hill, New York

Haner U-E (2005) Spaces for creativity and innovation in two established organizations. Creat Innov Manag 14(3):288-298

Hargadon AB (2008) Creativity that works. In: Zhou J, Shalley CE (eds) Handbook of organizational creativity, 1st edn. Taylor and Francis Group, New York, pp 323-343

Hargadon AB, Bechky BA (2006) When collections of creatives become creative collectives: a field study of problem solving at work. Organ Sci 17:484-500

Hitt MA (1975) The creative organization: tomorrow's survivor. J Creat Behav 9(4):283-290

Inzelt A (2003) Innovation process in Hungary. In: Shavinina LV (ed) The international handbook on innovation. Pergamon, Oxford, pp 859-880

Isaksen SG et al (2000-2001) Perceptions of the best and worst climates for creativity: preliminary validation evidence for the Situational Outlook Questionnaire. Creat Res J 13(2):171-184

James K, Drown D (2012) Organizations and creativity: trends in research, status of education and practice, agenda for the future. In: Mumford MD (ed) Handbook of organizational creativity, 1st edn. Elsevier, San Diego, pp 17-38

Kamel JAN (2006) (Org.) Engenharia do Entretenimento: Meu Vício, Minha Virtude, 1st edn. E-papers Serviços Editoriais Ltda., Rio de Janeiro

Kao J (2007) Innovation nation: how America is losing its innovation edge, why it matters, and what we can do to get it back. Simon \& Schuster, New York

Kaufman JC, Sternberg RJ (eds) (2006) The international handbook of creativity, 1st edn. Cambridge University Press, New York

Kelley T, Littman J (2001) The art of innovation: lessons in creativity from IDEO, America's leading design firm, 1st edn. Doubleday, New York

Koestler A (1964) The act of creation, 1st edn. Hutchinson \& Co., London

Kozbelt A, Beghetto RA, Runco MA (2010) Theories of creativity. In: Kaufman JC, Sternberg RJ (eds) The Cambridge handbook of creativity, 1st edn. Cambridge University Press, New York, pp 20-47

Kristensen T (2004) The physical context of creativity. Creat Innov Manag 13(2):89-96

Lang J, Lee C (2010) Workplace humor and organizational creativity. Int J Hum Resour Manag 21(1):46-60

Lundy O, Cowling A (1996) Strategic human resource management. Routledge, London

Magadley W, Birdi K (2009) Innovation labs: an examination into the use of physical spaces to enhance organizational creativity. Creat Innov Manag 18(4):315-325

Mainemelis C (2001) When the muse takes it all: a model for the experience of timelessness in organizations. Acad Manag Rev 26:548-565

Manimala M (2009) Creativity and entrepreneurship. In: Rickards T, Runco MA, Moger S (eds) The Routledge companion to creativity, 1st edn. Routledge, London, pp 119-131

Martins EC, Terblanche F (2003) Building organizational culture that stimulates creativity and innovation. Eur J Innov Manag 6(10):64-74

Mumford MD (2000) Managing creative people: strategies and tactics for innovation. Hum Resour Manag Rev 10:313-351

Nunes THL (2014) Formação de profissionais de engenharia para a produção de atividade do entretenimento. In: XLII Congresso Brasileiro de Educação em Engenharia. Juiz de Fora, Anais..., Associação Brasileira de Educação em Engenharia, Brasilia 
Mumford MD, Gustafson SB (1988) Creativity syndrome: integration, application, and innovation. Psychol Bull 103:27-43 Osborn AF (1953) Applied imagination: principles and procedures of creative thinking, 1st edn. Charles Scribner's Sons, New York

Perry-Smith JE, Shalley CE (2003) The social side of creativity: a static and dynamic social network perspective. Acad Manag Rev 28:89-106

Puccio GJ, Cabra JF (2010) Organizational creativity: a systems approach. In: Kaufman JC, Sternberg RJ (eds) The Cambridge handbook of creativity, 1st edn. Cambridge University Press, New York, pp 145-173

Rickards T (1999) Organizations interested in creativity. In: Runco MA, Pritzker ST (eds) Encyclopedia of creativity, vol 2, 1st edn. Academic Press, San Diego, pp 319-324

Rickards T, Bessant J (1980) The creativity audit: introduction of a new research measure during programmes for facilitating organizational change. R\&D Manag 10:67-75

Rogers EM (2003) Diffusion of innovations, 5th edn. Free Press, New York

Runco MA (2007) Creativity theories and themes: research, development and practice, 1st edn. Elsevier Academic Press, London

Runco MA (2008) Creativity and education. New Horiz Educ 56:107-115

Russ SW, Fiorelli JA (2010) Developmental approaches to creativity. In: Kaufman JC, Sternberg RJ (eds) The Cambridge handbook of creativity, 1st edn. Cambridge University Press, New York, pp 233-249

Sawyer RK (2012) Explaining creativity: the science of human innovation, 2nd edn. Oxford University Press, Cambridge

Sawyer RK (2013) Zig zag: the surprising path to greater creativity. Jossey-Bass, San Francisco

Shalley CE, Zhou J (2008) Organizational creativity research: a historical overview. In: Zhou J, Shalley CE (eds) Handbook of organizational creativity, 1st edn. Taylor and Francis, New York, pp 3-31

Siegel SM, Kaemmerer WF (1978) Measuring the perceived support for innovation in organizations. J Appl Psychol 63:553-562

Simonton DK (1990) History, chemistry, psychology, and genius: an intellectual autobiography of historiometry. In: Runco MA, Albert RS (eds) Theories of creativity. Sage, Newbury Park, pp 92-115

Simonton DK (2012) Fields, domains, and individuals. In: Mumford MD (ed) Handbook of organizational creativity, 1st edn. Elsevier, San Diego, pp 67-86

Stokols D, Clitheroe C, Zmuidzinas M (2002) Qualities of work environments that promote perceived support for creativity. Creat Res J 14(2):137-147

Styhre A, Sundgren M (2005) Managing creativity in organizations: critique and practices. Palgrave Macmillan, New York Unsworth K (2001) Unpacking creativity. Acad Manag Rev 26:289-297

VanGundy A (1987) Organizational creativity and innovation. In: Isaksen SG (ed) Frontiers of creativity research: beyond the basics. Bearly, Buffalo, pp 358-379

Vogel HL (2011) Entertainment industry economics: a guide for financial analysis, 8th edn. Cambridge University Press, Cambridge

Wallas G (1926) The art of thought. Harcourt, New York

West MA, Richter AW (2008) Climates and cultures for innovation and creativity at work. In: Zhou J, Shalley CE (eds) Handbook of organizational creativity, 1st edn. Taylor and Francis, New York, pp 211-236

Woodman RW, Sawyer JE, Griffin RW (1993) Toward a Theory of organizational creativity. Acad Manag Rev 18(2):293-321 Young JW (1940/1960) A technique for producing ideas, 1st edn. Waking Lion Press, West Valley City

\section{Submit your manuscript to a SpringerOpen ${ }^{\circ}$ journal and benefit from:}

- Convenient online submission

- Rigorous peer review

- Immediate publication on acceptance

- Open access: articles freely available online

- High visibility within the field

- Retaining the copyright to your article

Submit your next manuscript at $\boldsymbol{\nabla}$ springeropen.com 